\title{
Performance of Different Crop Establishment Methods on Growth, Weeds Dynamics and Yield in Rice-Rice Cropping Sequence
}

\author{
A. Vivekanandhini*, V. Ravi and K. Subrahmaniyan \\ Department of Agronomy, Tamil Nadu Rice Research Institute, Tamil Nadu Agricultural \\ University, Coimbatore-641003, Tamil Nadu, India \\ *Corresponding author
}

\section{A B S T R A C T}

\begin{tabular}{|l|}
\hline Ke y w o r d s \\
$\begin{array}{l}\text { Crop establishment, direct } \\
\text { seeded rice, non-puddled } \\
\text { transplanted rice, no till, } \\
\text { weed dynamics }\end{array}$ \\
\hline Article Info \\
\hline $\begin{array}{l}\text { Accepted: } \\
\text { 20 May 2018 } \\
\text { Available Online: } \\
\text { 10 June 2018 }\end{array}$ \\
\hline
\end{tabular}

\section{Introduction}

Rice is the staple food of the largest number of people on earth and more than 75 per cent of the rice cultivation is under irrigated condition Bouman et al., (2007). However, the irrigated rice production alone has the ability to increase productivity for increasing population, but it is threatened by increasing water scarcity (Barker and Molle, 2004). In India, most commonly practiced establishment method under irrigated rice cultivation is transplanting of seedlings into puddled soil reported by Rao et al., (2007).

In puddled condition the field was flooded for prolonged periods throughout the cropping period until shortly before harvest. The puddling have several disadvantages, including higher tillage costs, adverse effects on soil structure was confirmed by so and Ringrose-Voase, 2002) and high water requirement for crop establishment. The amount of irrigation water required for puddling varies from $100 \mathrm{~mm}$ Sudhir et al., (2011) to $544 \mathrm{~mm}$ (Bhuiyan, et al., 1995). Water input for crop establishment can be reduced by avoiding puddling. Transplanting can be done in non-puddled soil after saturating the soil and for dry seeded rice sowing was done on non-puddled dry soil, both reduce the water requirement for crop establishment (Balasubramanian and Hill, 2002). In Tamil Nadu, especially in Cauvery 
delta zones due to late release of canal water from dams and also sometimes late onset of rainfall there will be scarcity of water availability for cultivation of rice during initial stage for puddling. In such situation these nonpuddled and dry seeded rice establishment methods can be done as a contingency measures to reduce the water requirement during initial stage of cultivation.

\section{Materials and Methods}

\section{Details of study area}

A field experiment was conducted at Tamil Nadu Rice Research Institute, Aduthurai during 2016-2017 to study the effect of different crop establishment methods on growth weed dynamics and yield in rice- rice cropping sequence. The study area has mean annual rainfall of about $1078 \mathrm{~mm}$, majority of which was received during North East Monsoon. The climate of the region is characterized by a tropical climate with a hot dry summer (March-June), and extended wet period from September to February. The present cropping pattern found in the study area includes rice-rice. The soil was clayey loam with a $\mathrm{pH}$ of 7.0.

\section{Methodology}

In this study the performance of different crop establishment on growth, weeds dynamics and yield in rice-rice cropping sequence was evaluated. The experiments were conducted in randomized block design with four replications. Treatments consisted of $\mathrm{T}_{1}-\mathrm{Non}-$ puddled transplanted rice (NPTR) in kharif No Till (NT) in rabi, $\mathrm{T}_{2}-\mathrm{NPTR}$ in kharif Puddled transplanted rice (PTR) in rabi, $\mathrm{T}_{3}-$ Dry Seeded Rice (DSR) in kharif - NT in rabi, $\mathrm{T}_{4}-\mathrm{DSR}$ in kharif - PTR in rabi, $\mathrm{T}_{5}-$ PTR in kharif- NT in rabi and $\mathrm{T}_{6}-\mathrm{PTR}$ in both kharif and rabi. The varieties taken for experiment were ADT 43(105 days) during kharif 2016 and ADT 46 (130 days) during rabi 2016-17. The plot size of experiment was $10 \times 10 \mathrm{~m}$. A fertilizer schedule of 150: 50: 50 NPK $\mathrm{kg} / \mathrm{ha}$ was adopted as the common practice for the experiment.

Growth parameters were recorded at harvest for during both the seasons. Plant height was measured from the base of the plants to the tip of the longest leaf stretched and up to tip of the panicle and expressed in $\mathrm{cm}$. five hills were selected at random from each plot in sampling area. The collected samples were air dried, then oven dried at $70^{\circ} \pm 5^{\circ} \mathrm{C}$ for 72 hours. From the dry weight of samples dry matter production $\mathrm{ha}^{-1}$ was calculated and expressed in $\mathrm{kg} \mathrm{ha}^{-1}$. Grains from each net plot were cleaned; sun dried, weighed and adjusted to 14 per cent moisture content and the grain yield was expressed in $\mathrm{kg} \mathrm{ha}^{-1}$. The total weed density present in two randomly fixed $0.25 \mathrm{~m}^{2}$ area in each plot was counted at 45 DAS for both seasons. The weeds which were counted for weed density were used for recording dry weight of weeds. The dry weight of weeds was obtained after oven drying of weeds at 60$70^{\circ} \mathrm{C}$ till a constant weight. Weed dry weight was expressed as $\mathrm{g}$ per $0.25 \mathrm{~m}^{2}$.

\section{Results and Discussion}

\section{Effect on growth and yield attributes}

The plant height was higher in DSR $(111 \mathrm{~cm})$ than PTR $(98 \mathrm{~cm})$ during kharif 2016. During rabi 2016-17 the same was higher in DSR followed by PTR $(96 \mathrm{~cm})$. Meanwhile Dry matter production was also higher in same treatment during both seasons. The grain yield was higher in DSR (5355 kg ha-1) during kharif 2016 and DSR-PTR (7753 kg ha ${ }^{-1}$ ) during rabi 2016-17. As reported by Bhushan et al., (2007), that the yield of DSR was higher than that of the puddled transplanted rice. Only weeds are the major problem in DSR cultivation. 
Table.1 Effect of different crop establishment methods on Plant height $(\mathrm{cm})$ and Dry Matter Production $\left(\mathrm{Kgha}^{-1}\right)$

\begin{tabular}{|c|c|c|c|c|c|}
\hline \multicolumn{2}{|r|}{ Treatments } & \multicolumn{2}{|c|}{ Plant height (cm) } & \multicolumn{2}{|c|}{ DMP (Kg ha $\left.{ }^{-1}\right)$} \\
\hline & & $\mathbf{K}$ & $\mathbf{R}$ & $\mathbf{K}$ & $\mathbf{R}$ \\
\hline$\overline{T_{1}}$ & NPTR- NT & 93 & 86 & 8292 & 10090 \\
\hline$T_{2}$ & NPTR-PTR & 93 & 92 & 8300 & 11155 \\
\hline$\overline{T_{3}}$ & DSR-NT & 110 & 89 & 10247 & 10594 \\
\hline$\overline{T_{4}}$ & DSR- PTR & 111 & 96 & 10249 & 11473 \\
\hline$T_{5}$ & PTR- NT & 99 & 87 & 9243 & 10301 \\
\hline$T_{6}$ & PTR- PTR & 98 & 95 & 9245 & 11321 \\
\hline & SEd & 1.9 & 1.7 & 174 & 197 \\
\hline & $\mathrm{CD}(\mathrm{P}=0.05)$ & 3.9 & 3.4 & 364 & 413 \\
\hline
\end{tabular}

Table.2 Effect of different crop establishment methods on productive tillers (Nos. $\mathrm{m}^{-2}$ ) and grain yield $\left(\mathrm{Kgha}^{-1}\right)$

\begin{tabular}{|c|c|c|c|c|c|c|}
\hline \multirow{2}{*}{\multicolumn{2}{|c|}{ Treatments }} & \multicolumn{2}{|c|}{ Panicles (Nos. $\mathrm{m}^{-2}$ ) } & \multicolumn{3}{|c|}{ Grain yield $\left(\operatorname{Kgha}^{-1}\right)$} \\
\hline & & $\mathbf{K}$ & $\mathbf{R}$ & $\mathbf{K}$ & $\mathbf{R}$ & Total \\
\hline$T_{1}$ & NPTR- NT & 218 & 315 & 4820 & 6519 & 11339 \\
\hline$T_{2}$ & NPTR- PTR & 221 & 349 & 4813 & 7675 & 12488 \\
\hline$T_{3}$ & DSR- NT & 297 & 323 & 5328 & 6627 & 11955 \\
\hline$\frac{T_{4}}{4}$ & DSR- PTR & 309 & 364 & 5355 & 7721 & 13076 \\
\hline$T_{5}$ & PTR- NT & 244 & 315 & 4858 & 6561 & 11419 \\
\hline$\overline{\mathrm{T}_{6}}$ & PTR- PTR & 257 & 353 & 4862 & 7753 & 12615 \\
\hline & SEd & 6.8 & 8.9 & 131.2 & 189.3 & \\
\hline & $\mathrm{CD}(\mathrm{P}=0.05)$ & 14.2 & 18.6 & 274.2 & 395.4 & \\
\hline
\end{tabular}

Table.3 Effect of different crop establishment methods on weed density (Nos. $\mathrm{m}^{-2}$ ) and weed dry weight $\left(\mathrm{g} \mathrm{m}^{-2}\right)$

\begin{tabular}{|c|c|c|c|c|c|}
\hline \multicolumn{2}{|c|}{ Treatments } & \multicolumn{2}{|c|}{ Weed Density (Nos. $\mathbf{m}^{-2}$ ) } & \multicolumn{2}{|c|}{ Weed dry weight $\left(\mathrm{g} \mathrm{m}^{-2}\right)$} \\
\hline & & $\mathbf{K}$ & $\mathbf{R}$ & $\mathbf{K}$ & $\mathbf{R}$ \\
\hline$T_{1}$ & NPTR- NT & 15.3 & 17.9 & 31.34 & 36.90 \\
\hline$T_{2}$ & NPTR- PTR & 16.0 & 18.2 & 26.22 & 22.30 \\
\hline$T_{3}$ & DSR- NT & 23.3 & 30.1 & 31.53 & 43.40 \\
\hline$T_{4}$ & DSR- PTR & 22.7 & 28.5 & 28.42 & 25.30 \\
\hline$T_{5}$ & PTR- NT & 10.0 & 15.3 & 28.31 & 30.10 \\
\hline$T_{6}$ & PTR- PTR & 10.7 & 15.8 & 27.13 & 20.10 \\
\hline & SEd & 0.35 & 0.53 & 0.46 & 0.67 \\
\hline & $(P=0.05)$ & 0.72 & 1.10 & 0.96 & 1.41 \\
\hline
\end{tabular}

Note: K-Kharif 2016, R-Rabi2016-17, NPTR-Non-Puddled Transplanted Rice, DSR - Dry Seeded Rice, PTRPuddled Transplanted Rice, NT- No Till 
However availability of high-yielding shortduration varieties and new herbicides for weed control largely made suitable chance for high yielding of DSR than puddled transplanted rice. Meanwhile the panicles Nos. $\mathrm{m}^{-2}$ was also higher in DSR (309) during kharif 2016 and DSR followed by PTR (364) during rabi 2016-17.

\section{Effect on weed density and dry weight}

The weed density and dry weight were greatly influenced by different methods of establishment techniques. The lower weed density (10.0 \& 15.3 Nos. $\mathrm{m}^{-2}$ ) and weed dry weight $\left(27.13 \& 20.10 \mathrm{~g} \mathrm{~m}^{-2}\right)$ were observed under puddled transplanted rice during both Kharif and rabi seasons. High weed density and dry weight in DSR is due to greater weed competition than transplanted rice because weeds emerge before or at the same time as the rice. Therefore, heavy weed infestation is a major problem in direct-seeded rice and non-puddled rice cultivation. However the weeds can be managed by effective and timely management. The higher weed density $\left(31.53,31.34 \& 28.31\right.$ Nos. $\left.\mathrm{m}^{-2}\right)$ and weed dry weight $\left(43.40,36.90 \& 30.10 \mathrm{~g} \mathrm{~m}^{-2}\right.$ ) were observed in rabi season under DSR-NT, NPTR-NT \& PTR-NT respectively. Many studies have indicated that conventional tillage is superior to zero in weed control and grain yield was supported by co-worker Shad and De Datta, 1986.

It was concluded that the growth and yield attributes were higher in DSR and DSR- PTR. The weeds density and dry weight were higher in DSR and DSR-NT. Even though the weeds were higher in DSR that can be effectively controlled applying new herbicides. This shows that DSR gives similar or higher yield than PTR if weeds were controlled by timely and effective management. To manage the available water during water scarcity period, cultivation of non-puddled transplanted rice could be practiced besides dry seeded rice thereby puddling is avoided so as to reduce total irrigation water use without yield loss. Hence NPTR, DSR and NT crop establishment methods can be well adopted as a contingency plan to overcome water crisis during initial stage of rice cultivation.

\section{Acknowledgments}

I would like to extend sincere thanks to Tamil Nadu Rice Research Institute Tamil Nadu Agricultural University, for successfully coordinating the field trial during my Ph.D. research work.

\section{References}

Balasubramanian, V and J, Hill, 2002. Direct seeding of rice in Asia: emerging issues and strategic research needs for the 21st century. In: Pandey, S., Mortimer, M., Wade, L., Tuong, T., Lopez, K., Hardy, B. (Eds.), Direct Seeding: Research Issues and Opportunities. Proceedings of the International Workshop on Direct Seeding in Asian Rice System: Strategic Research Issues and Opportunities, International Rice Research Institute Bangkok, Thailand, Pp: 15-42.

Barker, R., Molle, F., 2004. Evolution of irrigation in south and Southeast Asia. Comprehensive Assessment Research Report. Comprehensive Assessment Secretariat, Colombo, Sri Lanka, pp. 45. Bhuiyan, S.I., Sattar, M.A., Khan, M.A.K., 1995. Improving water-use efficiency in rice irrigation through wet-seeding. Irrig. Sci. 16, 1-8.

Bhushan L, Ladha J K, Gupta R K, Singh S, Tirol-Padre A, Saharawat, Y S, Gathala M, Pathak H., 2007. "Saving of water and labor in rice-wheat system with notillage and direct-seeding technologies", Agron. J., 99, 1288-1296. 
Bouman, B.A.M., Lampayan, R.M., Tuong, T.P., 2007. Water Management in Irrigated Rice: Coping with Water Scarcity. International Rice Research Institute, Philippines, Los Baños, Philippines.

Rao AN, Johnson DE, Sivaprasad B, Ladha JK, Mortimer AM (2007) Weed management in Direct-seeded Rice. Adv Agron 93: 153-255

Shad and De Datta, 1986. Reduced tillage techniques for wetland rice as affected by herbicides. Soil and tillage research. 6, 291-303

So, H.B., Ringrose-Voase, A.J., 2000. Management of clay soils for rainfed lowland rice-based cropping systems: an overview. Soil Tillage Res. 56, 3-14.

Sudhir-Yadav, Humphreys, E., Kukal, S.S., Gill, G., Rangarajan, R., 2011. Effect of water management on dry seeded and puddled transplanted rice: Part 2: water balance and water productivity. Field Crops Res. 120, 123-132.

\section{How to cite this article:}

Vivekanandhini A., V. Ravi and Subrahmaniyan K. 2018. Performance of Different Crop Establishment Methods on Growth, Weeds Dynamics and Yield in Rice-Rice Cropping Sequence. Int.J.Curr.Microbiol.App.Sci. 7(06): 2207-2211.

doi: https://doi.org/10.20546/ijcmas.2018.706.261 